\title{
Types of intra-muscular opioids for maternal pain relief in labour (Review)
}

\author{
Elbourne D, Wiseman RREW
}

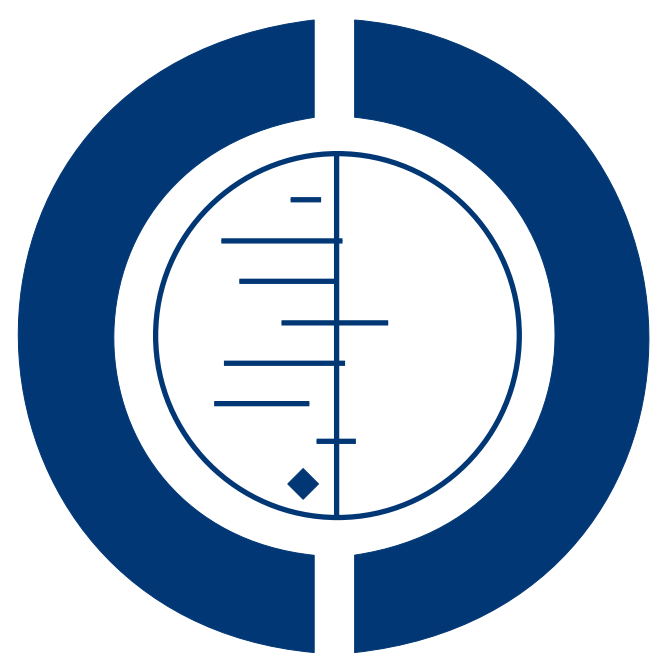

THE COCHRANE COLLABORATION $^{\circledR}$

This is a reprint of a Cochrane review, prepared and maintained by The Cochrane Collaboration and published in The Cochrane Library 2006, Issue 3

http://www.thecochranelibrary.com

\section{WILEY}

Types of intra-muscular opioids for maternal pain relief in labour (Review)

Copyright $\odot 2006$ The Cochrane Collaboration. Published by John Wiley \& Sons, Ltd. 
TABLE OF CONTENTS

HEADER . . . . . . . . . . . . . . . . . . . . . . . . . . . . . . . . . . . . . . . 1

REASON FOR WITHDRAWAL . . . . . . . . . . . . . . . . . . . . . . . . . . . . . . . . . . . . . . .

WHAT'S NEW . . . . . . . . . . . . . . . . . . . . . . . . . . . . . . . . . . . . . . 1

HISTORY . . . . . . . . . . . . . . . . . . . . . . . . . . . . . . . . . . . . . . .

SOURCES OF SUPPORT . . . . . . . . . . . . . . . . . . . . . . . . . . . . . . . . . . . . . . . . . . . .

Types of intra-muscular opioids for maternal pain relief in labour (Review)

Copyright $\odot 2006$ The Cochrane Collaboration. Published by John Wiley \& Sons, Ltd. 


\title{
[Intervention Review]
}

\section{Types of intra-muscular opioids for maternal pain relief in labour}

\author{
Diana Elbourne ${ }^{1}$, Richard REW Wiseman ${ }^{2}$ \\ ${ }^{1}$ Medical Statistics Unit, London School of Hygiene and Tropical Medicine, London, UK. ${ }^{2}$ Dept of Epidemiology and Population \\ Health, London School of Hygiene and Tropical Health, London, UK \\ Contact address: Diana Elbourne, Medical Statistics Unit, London School of Hygiene and Tropical Medicine, Keppel Street, London, \\ WC1E7HT, UK. Diana.Elbourne@1shtm.ac.uk. \\ Editorial group: Cochrane Pregnancy and Childbirth Group. \\ Publication status and date: Withdrawn from publication for reasons stated in the review, published in Issue 3, 2006. \\ Review content assessed as up-to-date: 8 July 1998. \\ Citation: Elbourne D, Wiseman RREW. Types of intra-muscular opioids for maternal pain relief in labour. Cochrane Database of \\ Systematic Reviews 2006, Issue 3. Art. No.: CD001237. DOI: 10.1002/14651858.CD001237.pub2. \\ Copyright (C) 2006 The Cochrane Collaboration. Published by John Wiley \& Sons, Ltd.
}

The editorial group responsible for this previously published document have withdrawn it from publication.

\section{REASON FOR WITHDRAWAL}

May 2006

The ' Types of intra-muscular opioids for maternal pain relief in labour' review (Elbourne D, Wiseman RA. Types of intra-muscular opioids for maternal pain relief in labour. The Cochrane Database of Systematic Reviews 1998, Issue 4. Art. No.: CD001237. DOI: 10.1002/14651858.CD001237.) has been withdrawn from Issue 3, 2006 of The Cochrane Library because it is out-of-date.

A new protocol is currently being prepared by a new review team to update this review: Parenteral analgesics for pain relief in labour.

\section{WHAT'S NEW}

Last assessed as up-to-date: 8 July 1998.

\begin{tabular}{|c|c|c|}
\hline Date & Event & Description \\
\hline 21 August 2008 & Amended & Converted to new review format. \\
\hline
\end{tabular}




\section{H I S T O R Y}

Protocol first published: Issue 2, 1998

Review first published: Issue 4, 1998

Date Event Description

22 May 2006 Amended Review withdrawn from publication in The Cochrane Library 2006, Issue 3.

\section{SOURCES OF SUPPORT}

\section{Internal sources}

- No sources of support supplied

\section{External sources}

- Nuffield Provincial Hospitals Trust, London, UK. 